\title{
Effect of Photoperiod and Melatonin on Volume and Cellular Parameters of Testis in Pinealectomized Rats
}

\author{
Efecto del Fotoperiodo y la Melatonina sobre el Volumen y \\ Parámetros Celulares de los Testículos en Ratas Pinealectomizadas
}

\author{
Murat Sırrı Akosman*; Vural Özdemir*; Nihal Taskiran**; Mehmet Aydın Akalan* \& Aziz Bülbüll**
}

AKOSMAN, M. S.; ÖZDEMIR, V.; TASKIRAN, N.; AKALAN, M. A.; BÜLBÜL, A. Effect of photoperiod and melatonin on volume and cellular parameters of testis in pinealectomized rats. Int. J. Morphol., 31(3):1062-1067, 2013.

SUMMARY: Mammalian reproductive axis is regulated by the combination of three fundamental tissues of neuroendocrine system including hypothalamus, hypophysis and gonads. In recent years, pineal gland has been included in this axis. The aim of the present study was to investigate the effect of $12 \mathrm{~L}$ (Light): $12 \mathrm{D}$ (Dark) photoperiod and melatonin administration $(0.5 \mathrm{mg} / \mathrm{kg} / \mathrm{day}$; subcutaneously) on testicular volume and cellular parameters of testis at the pinealectomized (PE) rats. For this aim, twelve adult rats were firstly pinealectomized and then divided into two groups as GI and GII randomly. The GI rats served as control group and received only normal saline, whereas GII rats were the melatonin administered group. It was found that the total testicular volume, diameter and epithelial height of seminiferous tubules and number and nuclear diameter of the interstitial cells of the testes were increased in the GII. However, increase in the interstitial cell number was not found statistically significant among groups. In conclusion, it was observed that the 12L:12D photoperiod and doses of melatonin given increased the investigated parameters in PE rats.

KEYWORDS: Cavalieri Method; Melatonin; Optical Fractionator; Pinealectomy; Stereology; Testis.

\section{INTRODUCTION}

The pineal gland has an important role on the control of reproductive system of the polyestric mammals. The hormone of the pineal gland; melatonin, has functions on adjustment of sexual development, gonadal steroidogenesis, sleep-wake cycle, seasonal adaptation and ovulation in addition to its antioxidant activity (Tamarkin et al., 1985; Uyar \& Alan, 2008; Pandi-Perumal et al., 2008). The melatonin secretion starts in the evening and continues during the night. Melatonin secretion reaches its highest level in the late of the night (Reiter et al., 1997).

The effect mechanism of melatonin on reproductive system previously investigated in humans (Balik et al., 2004), other mammals (Tamarkin et al.; Uyar \& Alan; Yilmaz et al., 2000) and avians (Chowdhury et al., 2010). Melatonin has an inhibitory effect on reproductive system of nonseasonable polyestric animals. This inhibition results as decrease of the Gonadotropin-releasing hormone ( $\mathrm{GnRH})$ release from hypothalamus and, consequently Follicle stimulating hormone (FSH) and Luteinizing hormone (LH) secretion decrease (Tamarkin et al.; Uyar \& Alan). Besides, melatonin stimulates the gonads of short day breeders (sheep, goat and deer) and inhibits those of long day breeders (horse, hamster and camel). Melatonin level increases and GnRH secretion stimulates in the sheep by onset of autumn as duration of daylight shortens (Tamarkin et al.; Uyar \& Alan). It is believed that the adult laboratory rats are not photoperiodic. However prepubertal rats which reared after birth on the short photoperiods have smaller organs than those on the long photoperiods. The melatonin inhibits GnRH-induced release of FSH and LH in the neonatals but not in the adults (Vanacek, 1999).

Melatonin previously administered for a long period (Kus et al., 2000, 2002), or at high doses (Kus et al., 2000, 2002) or for a short photoperiod (Gunduz \& Stetson, 1994) in several studies (the required information mentioned in discussion section). The aim of the present study was to

\footnotetext{
* Department of Anatomy, Faculty of Veterinary Medicine, Afyon Kocatepe University, Afyonkarahisar, Turkey.

** Department of Physiology, Faculty of Veterinary Medicine, Afyon Kocatepe University, Afyonkarahisar, Turkey.
} 
investigate the effect of administered dose of the melatonin and the 12L:12D photoperiod on testicular volume and cellular parameters of testes on adult PE rats.

\section{MATERIAL AND METHOD}

This study carried out by using 3 months aged twelve adult Wistar rats. All rats were PE under general anesthesia $(21.1 \mathrm{mg} / \mathrm{kg}$ ketamine and $4.2 \mathrm{mg} / \mathrm{kg}$ xylazine). All rats fed ad libitum throughout study period.

Pinealectomy. Scalp skin of rats was incised under anesthesia from the median line. The soft tissue on the upper part of the calvary was retracted. A 2-3 mm long hole was opened between the connection of the sagittal suture and right transversal suture by a dental drill. The pineal gland was extracted by iris forceps. The skin was sutured by $3 / 0$ silk (Aydin et al., 2008).

Experimental Procedures. The PE rats were then divided into two groups GI and GII randomly. The GI rats were served as control group and received only normal saline 0.2 $\mathrm{ml} /$ day; sc, and GII rats were administered melatonin 0.2 $\mathrm{ml} /$ day; sc $(0.5 \mathrm{mg} / \mathrm{kg} /$ day $)$.

All injections were performed between 21:00-23:00 daily in day 44. Animals were sacrificed by cervical dislocation and total hearth perfusion was performed. All left testes were collected and fixed in $10 \%$ buffered neutral formaldehyde solution. After two weeks all testes were totally embedded in paraffin and sliced serially throughout as $40 \mu \mathrm{m}$ in thickness. Every $20^{\text {th }}$ section was collected on glass slides. These sections were stained by the Giemsa (Giemsa's azur eosin methylene blue solution) stain. The total testicular volume, diameter and epithelial height of seminiferous tubules, number and nuclear diameter of interstitial cells of the testes were estimated in these slides.

Measurements. The diameter and epithelial height of seminiferous tubules and the nuclear diameter of interstitial cells were measured using Olympus $\mathrm{BH} 2$ microscope having $3.2 \mathrm{mp}$ Cmex camera attached and further connected to computerized image focus software (Orhan et al., 2004; Tas et al., 2010; Yenilmez et al., 1995).

Total Testicular Volume. All glass slides were fixed on the platform and their 1/1 scale photos were taken. A $2.5 \mathrm{~mm}$ spaced point grid was placed on those images on computer screen in order to measure the total volume by Cavalieri method (Gundersen et al., 1988). The calculations were then performed by the following formula:

$$
\mathrm{V}=\mathrm{t} \times \mathrm{a} / \mathrm{p} \times \Sigma \mathrm{P} \mathrm{cm}
$$

Interstitial Cell Number. The counting procedure was performed on interstitial cell nucleus as counting units according to optical fractionator method (Gundersen, 1986; Gundersen et al.; West et al., 1991; Myers et al., 2004). The interstitial cell number was estimated using Shtereom I software (Oguz et al., 2007), Olympus BH2 light microscope (Lang MS 316) with motorized stage (for progress in steps on $\mathrm{X}$ and $\mathrm{Y}$ axis) and 3.2 MP Cmex camera (Euromex, Holland), with x100 oil-immersion lens objective. The thickness of the tissue measured and the movements in $\mathrm{Z}$ axis were controlled by a microcator (Heidenhain, Germany). The area of the counting frame and the step length for $\mathrm{X}$ and $\mathrm{Y}$ axis was $2209 \mu \mathrm{m}^{2}, 1100$ $\mu \mathrm{m}$, and $1100 \mu \mathrm{m}$ respectively. The disector height was determined as $10 \mu \mathrm{m}$.

The total cell number was estimated according to following formula (West et al.);

$$
\mathrm{N}=1 / \mathrm{F}_{\text {ssf }} \times 1 / \mathrm{F}_{\text {hsf }} \times 1 / /_{\text {Fasf }} \times \sum \mathrm{Q}-
$$

$\mathrm{F}_{\text {ssf }}$ : Section Sampling Fraction ( $\mathrm{SSF}=1 / 20$ ),

$\mathrm{F}_{\text {hsf }}$ : Height Sampling Fraction. The mean section thickness divided to the height of the disector $(\sim 25 \mu \mathrm{m} / 10 \mu \mathrm{m})$,

$\mathrm{F}_{\text {asf: }}$ : Area Sampling Fraction. X-Y step lengths multiplied together and divided to the frame area $((1100 \mu \mathrm{m} \times 1100 \mu \mathrm{m}) /$ $\left.2209^{2} \mu \mathrm{m}\right)$,

$\Sigma$ Q-; Number of counted interstitial cells.

Statistical Analysis. All values are presented as mean \pm SE, for statistical evaluation of the data, paired T-Test was used.

\section{RESULTS ANS DISCUSSION}

All testes were evaluated in this study in normal anatomical appearance. The seminiferous tubules and their epithelials were in normal condition. The interstitial cells were containing large nucleuses and peripherally disposed heterochromatin areas.

Data about the total volume of testes, interstitial cell number, diameter and epithelial height of seminiferous tubules, and nuclear diameters of Interstitials cells were presented in Table I.

All parameters were increased in GII different from the GI as estimated and these are statistically significant differences except interstitial cell number (Fig. 1). 
Table I. The mean values of the parameters.

\begin{tabular}{lccc} 
Parameter & GI & GII & P value \\
\hline Testicle volume $\left(\mathrm{cm}^{3}\right)$ & $0.58 \pm 0.01$ & $0.72 \pm 0.02$ & $0.001^{* * *}$ \\
Diameter of seminiferous tubules $(\mu \mathrm{m})$ & $258.40 \pm 4.01$ & $272.99 \pm 3.31$ & $0.019^{*}$ \\
Epithelial height of seminiferous tubules $(\mu \mathrm{m})$ & $75.85 \pm 2.58$ & $83.36 \pm 0.30$ & $0.016^{*}$ \\
Nuclear diameter of Inters titial cell $(\mu \mathrm{m})$ & $5.71 \pm 0.05$ & $5.84 \pm 0.02$ & $0.059^{*}$ \\
Inters titial Cell Number (num/tes) & 69x10 $(\mathrm{CE}: 0.07)$ & $76 \times 105(\mathrm{CE}: 0.08)$ & $\mathrm{NS}$ \\
\hline
\end{tabular}

$* \mathrm{P}<0.05, * * * \mathrm{p}<0.001, \mathrm{NS}$ : Not significant.

Effects of the melatonin have been investigated previously (Karakas \& Gündüz, 2003; Ng \& Ooi, 1990; Ooi \& Ng, 1989; Ozturk et al., 1999; Sarabia et al., 2009). It has been reported that the external melatonin administration, independent from the epiphysial gland, inhibits the testicular development in juvenile hamster which was born in the short photoperiod (Gunduz \& Stetson, 1994). However, the same experimental procedure was performed on group of adult hamsters and controversial results obtained from the juveniles (Hoffman, 1973). This controversy may depend on the photoperiodic history of the animal because former photoperiod essentially influences the effect of the melatonin on the reproductive system (Gunduz \& Stetson). It is known that the reproductive activity in Mongolian gerbil affects by the photoperiod. But under long photoperiod did not effect the testicular volume and weight among non-PE gerbils and intact + melatonin administered gerbils and PE + melatonin administrated gerbils (Karakas \& Gündüz). In rats, pinealectomy increases the testicular weight while melatonin administration decreases the testicular weight in non-pinealectomized rats (Kus et al., 2000). According to Carneicelli et al. (1963) and Charlton et al. (1976), pinealectomy increases the testicular weight in adult animals except hamsters while others didn't observe a statistically significances on the adult rats (Castro $e t$ al., 2002; Roth, 1964).

In this research, it was found that the diameters of the seminiferous tubules in GII increased after external melatonin administrations. In a research of Castro et al., no difference were detected between non-PE and PE group. The parallel results were obtained as explained above (Ozturk et al.). However, melatonin administration in late afternoon had decreased diameter of seminiferous tubule in non-PE hamster and mice ( $\mathrm{Ng} \&$ Ooi; Ooi \& $\mathrm{Ng})$. Nonetheless, if the antioxidant activity considered of the melatonin, we noted that melatonin administration increased the diameter of the seminiferous tubules in the diabetic rats (Guneli et al., 2008), healed the harmful effects of the radiation in the testis, restarted the spermatogenesis (Hussein et al., 2006) and protected the epithelial height of the seminiferous tubule in poisoned animals by pesticides (Sarabia et al.). In addition to these findings, it was found that the exogenous melatonin administration protect testis towards the oxidative stressinduced tissue damage emerges after pinealectomy (Tasdemir et al., 2012).

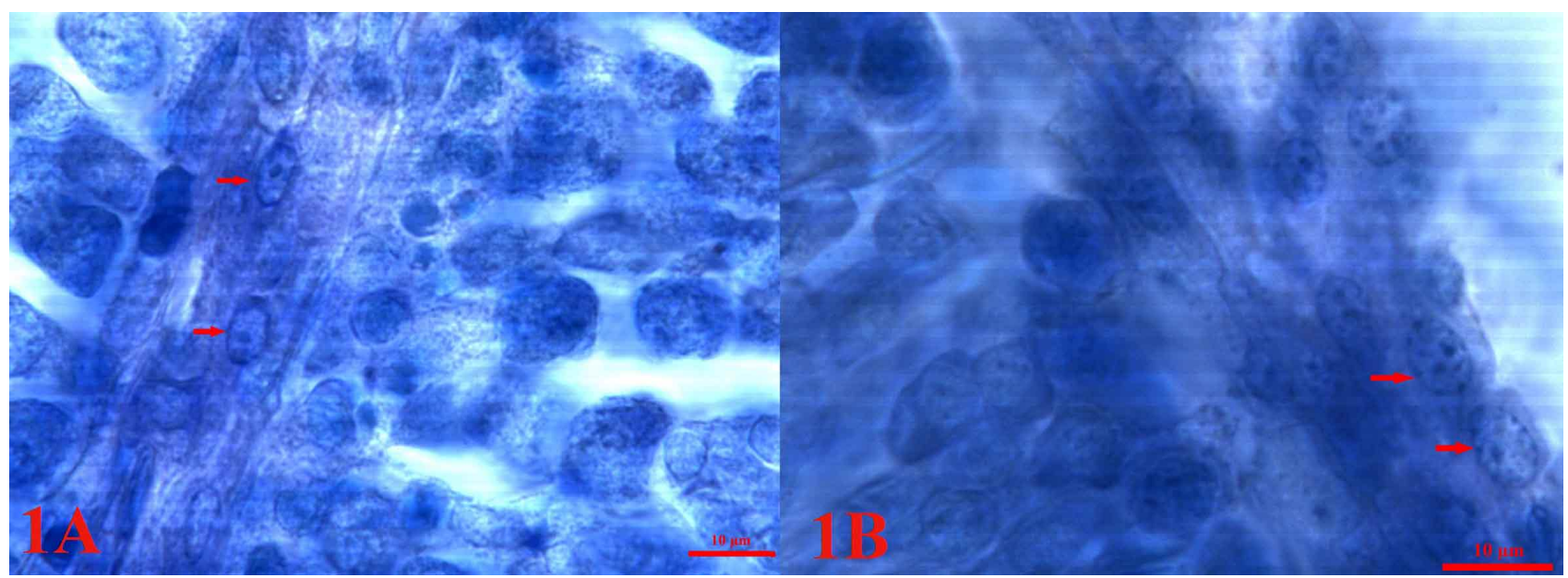

Fig. 1. Arrows are indicating the interstitial cell nucleuses in the interstitial area, the diameter of the interstitial cells nucleus increased in the Pinealectomized+Melatonin group, Giemsa (Giemsa's azur eosin methylene blue solution) staining method, $40 \mu \mathrm{m}$ thick sections; A. Interstitial cells of the Pinealectomized group x1000; B. Interstitial cells of the Pinealectomized+Melatonin group x1000. 


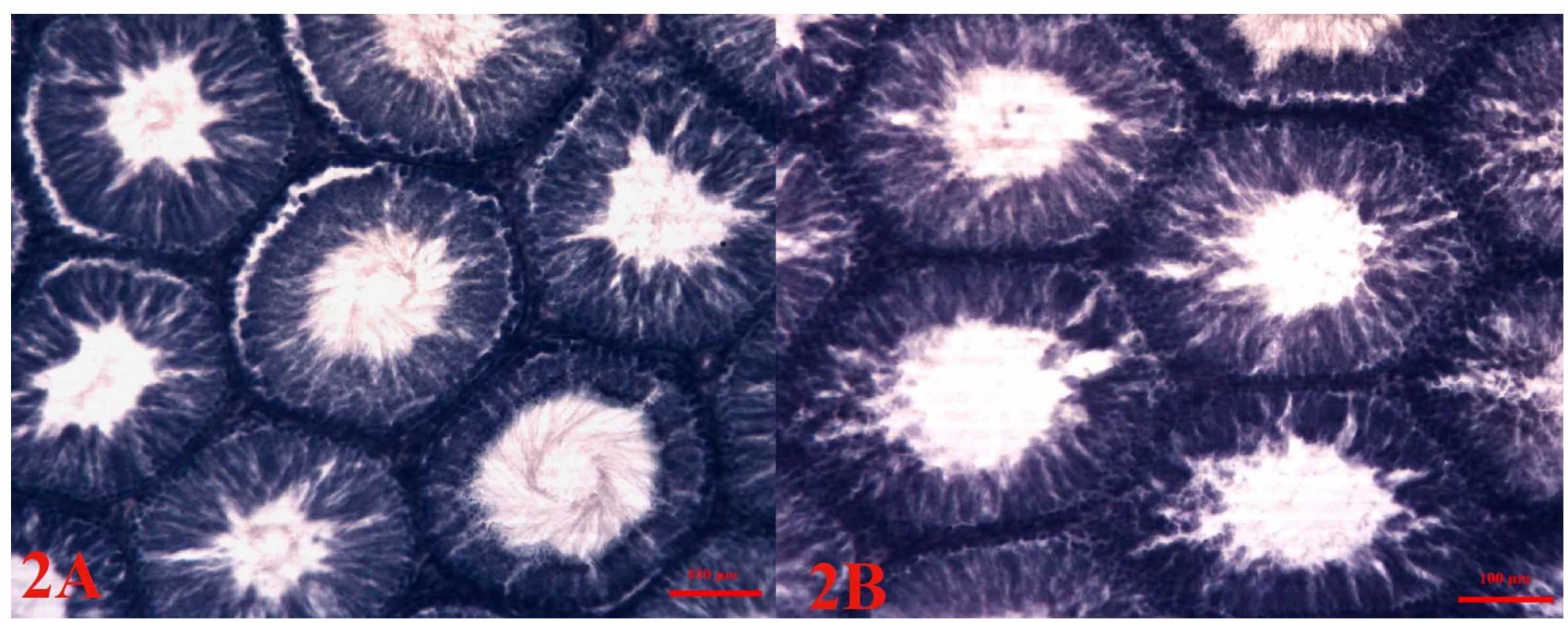

Fig. 2. The diameter of the seminiferous tubule and epithelial height increased in the Pinealectomized+Melatonin group, Giemsa(Giemsa's azur eosin methylene blue solution) staining method, $40 \mu \mathrm{m}$ thick sections; A. Seminiferous tubule of the Pinealectomized group x100;

B. Seminiferous tubule of the Pinealectomized+Melatonin group x100.

In the present study, the nuclear diameter of the Interstitials cells increased in GII. But the melatonin was downsized the nucleus of interstitial cells and became angular in the non-PE hamsters and mices (Ng \& Ooi; Ooi \& $\mathrm{Ng}$ ). Contrary to the results, interstitials cells were of normal anatomical appearance in this study. Besides, Kus et al. (2000), have reported that the PE rats have large nucleus in interstitials cells. The radiation has led to impairment of interstitial cell aggregates, decreases interstitial cell number in rats, however melatonin has increases interstitial cells number, and those aggregates (Hussein et al.).

Administration of melatonin has negative effects on testis (Gunduz \& Stetson; Kus et al., 2000), seminiferous tubule (Ng \& Ooi; Ooi \& Ng) and Interstitials cells ( $\mathrm{Ng} \&$ Ooi; Ooi $\& \mathrm{Ng}$ ). All these reports are contrary to present data and those differences might be depend on the use of the prepubertal animals, different species, high melatonin doses, non-PE animals and photoperiod. In conclusion, we have found that physiological dose of melatonin increased the total testicular volume, epithelial height and diameter of seminiferous tubules, nuclear diameter and number of interstitial cells in PE adult rats had 12L:12D photoperiod.

\section{ACKNOWLEDGEMENTS}

This research was achieved at the Afyon Kocatepe University, Research Animals Center, by authorization of Research Animals Ethics Commission of the Afyon Kocatepe University (AKUHADYEK-Reference Number-19-11).
AKOSMAN, M. S.; ÖZDEMI'R, V.; TASKIRAN, N.; AKALAN, M. A.; BÜLBÜL, A. Efecto del fotoperiodo y la melatonina sobre el volumen y parámetros celulares de los testículos en ratas pinealectomizadas. Int. J. Morphol., 31(3):1062-1067, 2013.

RESUMEN: El eje reproductivo de los mamíferos está regulado por la combinación de tres tejidos fundamentales del sistema neuroendocrino, incluyendo el hipotálamo, hipófisis y las gónadas. En los últimos años, la glándula pineal se ha incluido en este eje. El objetivo fue investigar el efecto del fotoperíodo $12 \mathrm{~L}$ (Luz):12O (oscuridad) y la administración de melatonina $(0,5 \mathrm{mg} / \mathrm{kg} /$ día, vía subcutánea) sobre el volumen testicular y los parámetros celulares del testículo en ratas pinealectomizadas (RP). Doce ratas adultas fueron pinealectomizadas y divididas en dos grupos, GI y GII de manera aleatoria. Las ratas del GI sirvieron como grupo de control y recibieron sólo solución salina normal, mientras que a las ratas del GII se les administró melatonina. Se encontró que el volumen total, diámetro y altura del epitelio de los túbulos seminíferos de los testículos, y el número y diámetro nuclear de las células intersticiales se incrementaron en el GII. Sin embargo, el aumento en el número de las células intersticiales no fue significativo entre los grupos. En conclusión, se observó que el fotoperíodo $12 \mathrm{~L}: 12 \mathrm{O}$ y la dosis administrada de melatonina aumentan los parámetros investigados en RP.

PAlabras ClaVe: Método Cavalieri; Melatonina; Fraccionador óptico; Pinealectomía; Estereología; Testículo. 


\section{REFERENCES}

Aydin, M.; Canpolat, S.; Kuloglu, T.; Yasar, A.; Colakoglu, N. \& Kelestimur, H. Effects of pinealectomy and exogenous melatonin on ghrelin and peptide YY in gastrointestinal system and neuropeptide $\mathrm{Y}$ in hypothalamic arcuate nucleus: immunohistochemical studies in male rats. Regul. Pept., 146(13):197-203, 2008.

Balik, A.; Kretschmannová, K.; Mazna, P.; Svobodová, I. \& Zemkova, H. Melatonin action in neonatal gonadotrophs. Physiol. Res., 53(Suppl. 1):153-66, 2004.

Carneicelli, A.; Saba, P.; Cella, P. L. \& Marescotti, V. Effects of epiphysectomy on karyometry of hypotyhalamic nuclei in rats. Folia Endocrinol., 16:229-34, 1963.

Castro, A. C. S.; Queiroz, G. F.; Nogueira, J. C.; Coimbra, C. C.; Reis, A. M.; Marubayashi, U. \& Yamasaki, K. Effect of pinealectomy, adrenalectomy, pinealectomy plus adrenalectomy upon the quantification of spermatogenic cells of adult rats. Arq. Bras. Med. Vet. Zootec., 54(3):267-72, 2002.

Charlton, H. M.; Grocock, C. A. \& Ostberg, A. The effects of pinealectomy and superior cervical ganglionectomy on the testis of the vole (Microtus agrestis). J. Reprod. Fertil., 48(2):377-9, 1976.

Chowdhury, V. S.; Yamamoto, K.; Ubuka, T.; Bentley, G. E.; Hattori, A. \& Tsutsui, K. Melatonin stimulates the release of gonadotropin-inhibitory hormone by the avian hypothalamus. Endocrinology, 151(1):271-80, 2010.

Gundersen, H. J. Stereology of arbitrary particles. A review of unbiased number and size estimators and the presentation of some new ones, in memory of William R. Thompson. $J$. Microsc., 143(Pt. 1):3-45, 1986.

Gundersen, H. J.; Bendtsen, T. F.; Korbo, L.; Marcussen, N.; Moller, A.; Nielsen, K.; Nyengaard, J. R.; Pakkenberg, B.; Sorensen, F. B.; Vesterby, A. \& West, M. J. Some new, simple and efficient stereological methods and their use in pathological research and diagnosis. APMIS, 96(5):379-94, 1988.

Gunduz, B. \& Stetson, M. H. Effects of photoperiod, pinealectomy, and melatonin implants on testicular development in juvenile Siberian hamsters (Phodopus sungorus). Biol. Reprod., 51(6):1181-7, 1994.

Guneli, E.; Tugyan, K.; Ozturk, H.; Gumustekin, M.; Cilaker, S. \& Uysal, N. Effect of melatonin on testicular damage in streptozotocin-induced diabetes rats. Eur. Surg. Res., 40(4):354-60, 2008.

Hoffman, K. The influence of photoperiod and melatonin on testis size, body weight, and pelage colour in the Djungarian hamster (Phodopus sungorus). J. Comp. Physiol., 85:267-82, 1973.
Hussein, M. R.; Abu-Dief, E. E.; El-Ghait, A. T.; Adly, M. A. \& Abdelraheem, M. H. Morphological evaluation of the radioprotective effects of melatonin against X-ray-induced early and acute testis damage in Albino rats: an animal model. Int. J. Exp. Pathol., 87(3):237-50, 2006.

Karakas, A. \& Gündüz, B. Melatonin implants have no effect on the testis volume and body weight in Mongolian gerbils. Turk. J. Biol., 27:209-14, 2003.

Kus, I.; Sarsilmaz, M.; Ogetürk, M.; Yilmaz, B.; Kelestimur, H. \& Oner, H. Ultrastructural interrelationship between the Pineal gland and the testis in the male rat. Arch. Androl., 45(2):119-24, 2000.

Kus, I.; Akpolat, N.; Ozen, O. A.; Songur, A.; Kavakli, A. \& Sarsilmaz, M. Effects of melatonin on Interstitial cells in pinealectomized rat: an immunohistochemical study. Acta Histochem., 104(1):93-7, 2002.

Myers, M.; Britt, K. L.; Wreford, N. G.; Ebling, F. J. \& Kerr, J. B. Methods for quantifying follicular numbers within the mouse ovary. Reproduction, 127(5):569-80, 2004.

$\mathrm{Ng}$, T. B. \& Ooi, V. E. Effect of pineal indoles on testicular histology of mice. Arch. Androl., 25(2):137-45, 1990.

Oguz, E. O.; Conkur, E. S. \& Sari, M. Shtereom I simple windows based software for stereology, volume and number estimations. Image Anal. Stereol., 26:45-50, 2007.

Ooi, V. E. \& Ng, T. B. Histological studies on the effects of pineal 5-methoxyindoles on the reproductive organs of the male golden hamster. J. Pineal Res., 7(4):315-24, 1989.

Orhan, I.; Hayit, H.; Duksal, I.; Ozercan, I. H.; Firdolas F. \& Semercioz, A. Tek taraflı testis torsiyonunda paf antagonistinin kars1 taraf testisin iskemik hasarındaki koruyucu etkinligi. T. Urol. Dergi., 30(1):11-6, 2004.

Ozturk, A.; Baltaci, A. K.; Bediz, C. S.; Gungor, S. \& Ates, A. Cinko ve melatonin eksikliginin rat testisleri uzerine histolojik etkileri. SDU. Tip. Fak. Derg., 6(4):41-6, 1999.

Pandi-Perumal, S. R.; Trakht, I.; Srinivasan, V.; Spence, D. W.; Maestroni, G. J.; Zisapel, N. \& Cardinali, D. P. Physiological effects of melatonin: role of melatonin receptors and signal transduction pathways. Prog. Neurobiol., 85(3):335-53, 2008.

Reiter, R. J.; Carneiro, R. C. \& Oh, C. S. Melatonin in relation to cellular antioxidative defense mechanisms. Horm. Metab. Res., 29(8):363-72, 1997.

Roth, W. D. Comments on J. Ariens Kapper's review and observations on pineal activity. Am. Zool., 4:53-7, 1964.

Sarabia, L.; Maurer, I. \& Bustos-Obregon, E. Melatonin prevents damage elicited by the organophosphorous pesticide diazinon on the mouse testis. Ecotoxicol. Environ. Saf., 72(3):938-42, 2009. 
AKOSMAN, M. S.; ÖZDEMIR, V.; TASKIRAN, N.; AKALAN, M. A.; BÜLBÜL, A. Effect of photoperiod and melatonin on volume and cellular parameters of testis in pinealectomized rats. Int. J. Morphol., 31(3):1062-1067, 2013.

Tamarkin, L.; Baird, C. J. \& Almeida, O. F. Melatonin: A coordinating signal for mammalian reproduction. Science, 227(4688):714-20, 1985.

Tas, M.; Saruhan, B. G.; Kurt, D.; Yokus, B. \& Denli, M. Protective role of lycopene on aflatoxin b1 induced changes sperm characteristics and testicular damages in rats. Kafkas Univ. Vet. Fak. Derg., 16(4):597-604, 2010.

Tasdemir, S.; Samdanci, E.; Parlakpinar, H.; Polat, A.; Tasdemir, C.; Cengiz, N.; Sapmaz, H. \& Acet, A. Effects of pinealectomy and exogenous melatonin on the brains, testes, duodena and stomachs of rats. Eur. Rev. Med. Pharmacol. Sci., 16(7):8606, 2012.

Uyar, A. \& Alan, M. Koyunlarda erken anostrus doneminde melatonin uygulamalarinin ovulasyon ve gebelik uzerine etkisi. Yyu. Vet. Fak. Derg., 19(1):47-54, 2008.

Vanecek, J. Inhibitory effect of melatonin on GnRH-induced LH release. Rev. Reprod., 4(2):67-72, 1999.

West, M. J.; Slomianki, L. \& Gundersen, H. J. Unbiased stereological estimation of the total number of neurons in the subdivisions of the rat hippocampus using the optical fractionator. Anat. Rec., 231(4):482-97, 1991.

Yenilmez, E.; Yamanturk, P. \& Aytekin, Y. Etanolun sıçan testisi ve fertilitesi üzerine etkileri. Turk. Patol. Derg., 11(1):1-13, 1995.

Yilmaz, B.; Kutlu, S.; Mogulkoc, R.; Canpolat, S.; Sandal, S.; Tarakci, B. \& Kelestimur, H. Melatonin inhibits testosterone secretion by acting at hypothalamo-pituitary-gonadal axis in the rat. Neuro. Endocrinol. Lett., 21(4):301-6, 2000.

\author{
Correspondence to: \\ Murat Sırrı Akosman \\ Afyon Kocatepe University \\ Faculty of Veterinary Medicine \\ Department of Anatomy \\ Afyonkarahisar \\ Turkey
}

Phone: +902722281312-232

Fax: +902722281349

Email: akosmans@yahoo.com

Received: 19-12-2012

Accepted: 27-04-2013 